\title{
The Effect of Bolus Taste on Oral and Pharyngeal Transit of Patients with Stroke
}

\author{
Efeito do Sabor no Trânsito Oral e Faríngeo de Pacientes com Acidente Vascular Cerebral \\ Leda Maria Tavares Alves', Soraia Ramos Cabette Fabio ${ }^{2}$, \\ Roberto Oliveira Dantas ${ }^{3}$
}

\begin{abstract}
Objective. To evaluate the effect of different bolus flavors in oral and pharyngeal transit duration of patients with stroke and normal volunteers. Method. The investigation had the participation of 36 patients (44-82 years, mean age: 63 years) with occurrence of stroke from 1 month to 84 months (median: 5.5 months) and 30 normal subjects (33-85 years, mean age: 59 years) who comprised the control group. The scintigraphic method was used to evaluate the oral and pharyngeal transit. Each subject swallowed in random sequence $5 \mathrm{~mL}$ of a liquid bolus of bitter, sour, sweet, and neutral taste, all labeled with $37 \mathrm{MBq}$ of ${ }^{99 \mathrm{~m}}$ Technetium coupled with phytate. Results. Oral transit was longer in patients with stroke than in the control subjects for the sweet, bitter and sour tastes. Pharyngeal transit and clearance was longer in patients with stroke for the sweet and bitter tastes. In both groups there were no differences between neutral, sweet, sour or bitter tastes. Conclusion. Bolus tastes evaluated did not change oral and pharyngeal transit in normal subjects and patients with stroke.
\end{abstract}

Keywords. Stroke, Cerebrovascular Disease, Dysphagia, Swallowing, Bolus Taste.

Citation. Alves LMT, Fabio SRC, Dantas RO. The Effect of Bolus Taste on Oral and Pharyngeal Transit of Patients with Stroke.

\section{RESUMO}

Objetivo. Avaliar o efeito do sabor na duração do trânsito oral e faringeano de pacientes com Acidente Vascular Cerebral (AVC) e voluntários normais. Método. Participaram da investigação 36 pacientes com AVC (44-82 anos, média: 63 anos), ocorrido de 1 mês a 84 meses (mediana: 5,5 meses), e 30 voluntários controles (33-85 anos, média: 59 anos). Foi utilizado a cintilografia para avaliar os trânsitos oral e faringeo. Em sequência aleatória foi ingerido $5 \mathrm{~mL}$ de bolo líquido de sabores amargo, azedo, doce e neutro, com $37 \mathrm{MBq}$ de ${ }^{99 \mathrm{~m}}$ Tecnécio ligado a fitato. Resultados. $\mathrm{O}$ trânsito oral foi maior em pacientes com AVC do que nos indivíduos controles, para os sabores doce, amargo e azedo. O trânsito faríngeo e a depuração foram mais longos em pacientes com AVC para os gostos doce e amargo. Em ambos os grupos não houve diferença entre os sabores neutro, doce, azedo e amargo. Conclusáo. $\mathrm{O}$ gosto dos bolos deglutidos testados não alteraram os trânsitos oral e faríngeo de indivíduos normais e de pacientes com AVC.

Unitermos. Disfagia, Deglutição, Acidente Vascular Cerebral, Sabor.

Citaçáo. Alves LMT, Fabio SRC, Dantas RO. Efeito do Sabor no Trânsito Oral e Faríngeo de Pacientes com Acidente Vascular Cerebral.
Study performed at Medical School of Ribeirão Preto, University of São Paulo, Ribeiráo Preto-SP, Brazil.

1.Doctoral Degree by the Department of Ophthalmology, Otorhinolaryngology, Head and Neck Surgery - FMRPUSP, Ribeirão Preto-SP, Brasil.

2.Neurologist of the Department of Neurosciences, Unit of Cerebrovascular Diseases - FMRPUSP, Ribeirão Preto-SP, Brasil.

3.Associate Professor of Gastroenterology, Department of Medicine - FMRPUSP, Ribeirāo Preto-SP, Brasil.
Endereço para correspondência: Roberto Oliveira Dantas

Departamento de Clínica Médica Faculdade de Medicina de Ribeirão Preto - USP CEP 14049-900, Ribeirão Preto, SP, Brasil Tel/Fax.: (16) 36022457 / (16) 36020229

E-mail: rodantas@fmrp.usp.br 


\section{INTRODUCTION}

Stroke is a clinical syndrome described as a focal neurological deficit caused by changes in cerebral blood flow which has consequences in cognitive and sensorimotor plans, according to the affected area and its extension. Dysphagia occurs in $37 \%$ to $45 \%$ using screening tests and in $64 \%$ to $78 \%$ using instrumental tests ${ }^{1}$. Although swallowing difficulties improve naturally, in about $10 \%$ of patients problems can persist for more than six months ${ }^{2}$. Taste disorder in the first week after the onset of signs and symptoms of stroke are frequent, is associated with swallowing disorders and have a good prognosis ${ }^{3}$.

Taste has influence on respiration-swallowing coordination, duration of the preparatory phase of swallowing and in submentonian muscle activity ${ }^{4}$. It has been suggested that bolus taste may modify swallowing in patients with stroke $e^{5,6}$ and, associated with cold temperature, may have a role in the treatment of patients with stroke and dysphagia ${ }^{7-9}$. Sour bolus with cold temperature has a shorter pharyngeal transit than sour bolus at room temperature ${ }^{7-9}$.

Taste causes different autonomic nervous system responses, with sweet taste inducing the weakest response whereas the unpleasant tastes (salty, sour and bitter), inducing stronger responses, with the bitter taste inducing the strongest ones ${ }^{10}$. Sour taste resulted in the greatest amplitude of submental muscle contraction during swallowing, and is swallowed with more effort when compared with other tastes. Swallowing duration for sour, salty and bitter tastes were longer than for sweet and neutral tastes ${ }^{4}$. The different autonomic nervous system responses and the increase in submentonian muscle activity by taste could cause modification in oral and pharyngeal transit duration, in normal subjects and patients with stroke.

The aim of this investigation was to evaluate the effect of different bolus flavors in oral and pharyngeal transit duration of patients with stroke and normal volunteers. The hypothesis was that bolus taste, which causes a stronger muscle response during swallowing, also causes an alteration in the time of the bolus transit through the mouth and pharynx.

\section{METHOD}

The investigation had the participation of 36 patients, 21 men and 15 women, aged 44 to 82 years (mean: 63 years), with a history of occurrence of stroke from 1 month to 84 months (median: 5.5 months) and 30 subjects who comprised the control group, 13 men and 17 women, aged 33 to 85 years (mean: 59 years) without symptoms or diseases. Ten patients with stroke complained of dysphagia at the scintigraphic evaluation.

The study included patients with clinical diagnosis and results of computed tomography and/or magnetic resonance imaging of hemorrhagic $(\mathrm{n}=5)$ or ischemic $(n=31)$ stroke who were able to feed orally. Hemorrhagic stroke was seen in one patient on the right and in four in the left hemisphere, and isquemic stroke was seen in 14 patients in the right and in 17 patients in the left. The stroke affected the vertebrobasilar territory in 11 and the carotid territory in 25. Patients were excluded who were severely compromised, precluding the clinical and objective assessment of swallowing, those with severe cognitive impairment, those not able to feed orally, and those with other neurological disease. The study was approved by the Ethics Committee of the University Hospital of the Medical School of Ribeirão Preto, University of São Paulo, in October 23, 2006, protocol number HCRP $8343 / 2006$. All participants or caregivers gave written informed consent to participate in the investigation.

The subjects were evaluated sitting in front of a gamma camera (Sopha Vision DST, Sopha Medical Vision America, Twenburg, Ohio, USA) equipped with a collimator for low energy, high sensitivity and an apparatus for detecting emissions of ${ }^{99 \mathrm{~m}}$ Techinectium. All images were stored on computer equipment. The gamma - camera was positioned so as to include the mouth, pharynx and esophagus.

The subjects were studied while facing forward, head at midline and not moving during the scintigraphic examination. An external radioactive reference of the transition between pharynx and esophagus consisting of a needle filled with liquid technetium was attached to the skin of the neck over the cricoid cartilage. Each subject swallowed in random sequence $5 \mathrm{~mL}$ of a liquid bolus of bitter taste (prepared with $50 \mathrm{~mL}$ of water with $2 \mathrm{~g}$ of leaves of Peumus boldus, $\mathrm{pH}$ : 6.0), sour taste $(50 \mathrm{~mL}$ of water with $3 \mathrm{~g}$ of concentrated lemon juice, $\mathrm{pH}: 3.0$ ), sweet taste (50 mL of water with $3 \mathrm{~g}$ of sucrose, $\mathrm{pH}: 6.9$ ); 
and neutral taste (water, $\mathrm{pH}$ : 6.8), all labeled with 37 $\mathrm{MBq}$ of ${ }^{99 \mathrm{~m}}$ Technetium coupled with phytate. The subjects were instructed to keep the bolus in the oral cavity, supporting their head straight and then swallowing when the examiner gave them the command. This was given approximately three seconds after the start of image acquisition. Between recording sequences, the subjects were given a sip of unlabeled water to drink to wash out any isotope and bolus taste remaining in the mouth, pharynx or esophagus from a previous swallow.

A series of images of each swallow was acquired at $20 \mathrm{frames} / \mathrm{second}$ for 20 seconds for a total of 400 frames. Oral, pharyngeal and esophageal transits were analyzed after the delineation of regions of interest (ROI). The mouth was the region where the bolus was before the swallow. The pharynx was the region between the mouth and projection of the external reference. Time-activity curves were generated for the mouth and pharynx. From these time-activity curves, we measured the mouth transit duration and residues, the pharyngeal transit, pharyngeal clearance and pharyngeal residues with the computer program of the nuclear medicine equipment. Residue was defined as the counts remaining in each ROI after the swallow, expressed as the percentage of the counts delivered to each ROI. Transit duration was defined as the interval between the maximal counts and the completion of emptying seen in a ROI. Clearance was the total exposure time to the bolus in a ROI, which represents the interval between the arrival of the bolus head into the ROI and the departure of the bolus tail from the ROI. These measurements were demonstrated in previous publications ${ }^{11-14}$.

The statistical analysis of transit, clearance times and amount of residues was done using a linear model with mixed effects ${ }^{15}$. The tests were performed at the Center of Quantitative Analysis of the Medical School of Ribeirão Preto USP (CEMEQ - FMRPUSP). The results were adjusted to sex and age. They are reported as mean and standard deviation (SD), unless stated otherwise.

\section{RESULTS}

Oral transit was longer in patients with stroke than in the control group for the sweet, bitter and sour tastes, but not for neutral taste. There was no difference in oral residue between the control group and patients with stroke (Table 1).

Pharyngeal transit and clearance was longer in patients with stroke for the sweet and bitter tastes and the amount of residues in pharynx was increased in patients with stroke than controls, excepted for the sweet bolus taste (Table 2).

In each group, in all measurements performed, there was no difference between neutral, sweet, sour or bitter tastes, indicating that bolus taste does not change oral and pharyngeal transit and residues in normal subjects and patients with stroke. Lesion localization did not have influence on the results of the effect of bolus taste on swallowing.

\section{DISCUSSION}

Scintigraphy has shown to be a quantitative relevant method for the study of swallowing, due to the fact of being a noninvasive technique ${ }^{16}$. Oral-pharyngeal scintigraphic clearance is highly reliable, bolus volume dependent and has a high predictive value for regional dysfunction. Also, abnormal oral and pharyngeal residuals had positive predictive values over $90 \%$ for regional dysfunction ${ }^{17}$.

The loss of ability to perceive salty, sweet or sour tastes, and impaired oral central representation, are initially diagnosed in patients with hemispheric stroke, and in most cases the functional disorders persist for more than 18 months $^{18}$. Sensory alteration is associated with swallowing difficulty ${ }^{19}$. Central lesions involving taste pathways seem to generate perceptions of quantitative taste disorders (hemiageusia or hypoageusia), different of peripheral gustatory lesions which is recognized as qualitative taste disorder (dysgeusia). Central taste disorders may often go unnoticed by the physician and the patient $^{20}$. Another possibility is that although the patients have perception of bolus taste, they may have impairment of efferent motor response, the effect of taste does not causing an effective motor response in the mouth and pharynx.

The swallowing of a sour bolus results in stronger muscle contraction, which is demonstrated by the measurement of EMG activity, and thus justifies the possible use of a sour bolus as part of oropharyngeal dysphagia 
Table 1

Oral transit and residues after swallows of a neutral, sweet, sour and bitter bolus in patients with stroke $(n=36)$ and controls $(n=30)$. Mean (SD)

\begin{tabular}{|l|c|c|c|c|c|c|}
\hline & \multicolumn{3}{|c|}{ Transit (s) } & \multicolumn{3}{c|}{ Residue (\%) } \\
\hline Tastes & Controls & Stroke & $\boldsymbol{p}$ & Controls & Stroke & $\boldsymbol{p}$ \\
\hline Neutral & $0.53(0.34)$ & $0.60(0.33)$ & 0.16 & $12.1(9.3)$ & $15.6(7.9)$ & 0.73 \\
\hline Sweet & $0.53(0.33)$ & $0.73(0.44)$ & 0.01 & $15.7(12.0)$ & $15.0(9.6)$ & 0.65 \\
\hline Sour & $0.48(0.28)$ & $0.72(0.66)$ & 0.01 & $13.7(6.9)$ & $13.1(9.2)$ & 0.51 \\
\hline Bitter & $0.47(0.27)$ & $0.68(0.50)$ & 0.01 & $14.3(6.9)$ & $15.7(10.3)$ & 0.35 \\
\hline
\end{tabular}

Table 2

Pharyngeal transit, clearance and residues after swallows of a neutral, sweet, sour and bitter bolus in patients with stroke (n=36) and controls $(n=30)$. Mean (SD)

\begin{tabular}{|c|c|c|c|c|c|c|c|c|c|}
\hline \multirow{2}{*}{ Tastes } & \multicolumn{3}{|c|}{ Transit $(\boldsymbol{s})$} & \multicolumn{3}{c|}{ Clearance $(\boldsymbol{s})$} & \multicolumn{3}{c|}{ Residues (\%) } \\
\cline { 2 - 11 } & Controls & Stroke & $\boldsymbol{p}$ & Controls & Stroke & $\boldsymbol{p}$ & Controls & Stroke & $\boldsymbol{p}$ \\
\hline Neutral & $0.39(0.15)$ & $0.40(0.15)$ & 0.71 & $0.72(0.20)$ & $0.75(0.30)$ & 0.69 & $7.40(6.1)$ & $10.90(6.5)$ & 0.01 \\
\hline Sweet & $0.36(0.13)$ & $0.52(0.30)$ & $<0.01$ & $0.69(0.20)$ & $0.90(0.46)$ & 0.01 & $8.40(8.0)$ & $10.10(6.5)$ & 0.09 \\
\hline Sour & $0.38(0.13)$ & $0.49(0.23)$ & 0.07 & $0.68(0.19)$ & $0.81(0.24)$ & 0.03 & $6.30(3.8)$ & $10.40(6.9)$ & $<0.01$ \\
\hline Bitter & $0.40(0.14)$ & $0.44(0.15)$ & 0.31 & $0.72(0.17)$ & $0.80(0.28)$ & 0.26 & $7.10(5.2)$ & $11.40(7.2)$ & $<0.01$ \\
\hline
\end{tabular}

treatment $\mathrm{t}^{21}$. However, the sour bolus is the most difficult bolus taste to recognize by patients with stroke ${ }^{3}$. Among the patients included in this investigation, the identification of bitter and sour bolus tastes had a less frequent identification than sweet and neutral bolus tastes ${ }^{22}$. It is not clear if the alteration of EMG activity with the sour bolus is dependent on the perception of taste. Peripheral taste signals are modulated and relayed through the nucleus tractus solitarius and the taste nucleus of the thalamus projecting bilaterally onto the anterior insula ${ }^{23}$. The insula is the cortical site for taste processing in humans ${ }^{24}$. Taste pathways may be involved by the cerebrovascular lesion. Although there is a response of muscle function to bolus taste, the control subjects did not have alteration of oral and pharyngeal transit with the different boluses. It is possible that the swallowing in these normal subjects is not changed by bolus taste because the bolus response is already the most appropriate for the bolus volume and consistency swallowed. In patients with stroke, the swallow is impaired and the bolus characteristic might change the swallow to a similar behavior of normal subjects. It is not clear if the bolus taste alone has influence in oral and pharyngeal transit, but when associated with cold temperature, the pharyngeal transit is closer to that of controls $^{7-9}$.

The findings on the oral and pharyngeal transit of this investigation showed that there was no difference among the flavors for each group separately. As the initial hypothesis was that the flavors cause differences on the swallows, in terms of oral and pharyngeal transit duration, the results did not confirm this hypothesis. Previous investigation did not find difference between patients with stroke and controls in oral transit, pharyngeal transit and pharyngeal clearance after swallows of a $5 \mathrm{~mL}$ bolus of water, which has a neutral taste ${ }^{13}$. These patients were able to have oral feeding and most of them did not have dysphagia, thus the oral function seems to be preserved.

\section{CONCLUSION}

Therefore, we conclude that the duration of oral and pharyngeal transit and clearance are longer in stroke patients than in controls. The amount of pharyngeal residues after swallows is higher in stroke patients than in controls. The bolus taste alone does not affect the oral and pharyngeal swallowing in patients with stroke and normal subjects. 


\section{REFERENCES}

1.Martino R, Foley N, Bhogal S, Diamant N, Speechley M, Teasell R. Dysphagia after stroke. Incidence, diagnosis, and pulmonary complications. Stroke 2005;36:2756-63.

http://dx.doi.org/10.1161/01.STR.0000190056.76543.eb

2.Ferri CP, Schoenborn C, Kalra L, Acosta D, Guerra M, Huang Y, et al. Prevalence of stroke and related burden among older people living in Latin America, India and China. J Neurol Neurosurg Psychiatry 2011;82:1074-82.

http://dx.doi.org/10.1136/jnnp.2010.234153

3.Heckmann JG, Stössel C, Lang CJ, Neundörfer B, Tomandl B, Hummel T. Taste disorders in acute stroke: a prospective observational study on taste disorders in 102 stroke patients. Stroke 2005;36:1690-4. http://dx.doi.org/10.1161/01.STR.0000173174.79773.d3

4.Leow LP, Huckabee ML, Sharma S, Tooley TP. The influence of taste on swallowing apnea, oral preparation time, and duration and amplitude of submental muscle contraction. Chem Senses 2007;32:119-28.

http://dx.doi.org/10.1093/chemse/bj1037

5.Pelletier CA, Lawless HT. Effect of citric acid and citric acid sucrose mixtures on swallowing in neurogenic oropharyngeal dysphagia. Dysphagia 2003;18:231-41.

http://dx.doi.org/10.1007/s00455-003-0013-y

6.Lee KL, Kim DY, Kim WH, et al. The influence of sour taste on dysphagia in brain injury: blind study. Ann Rehabil Med 2012;36:365-70.

http://dx.doi.org/10.5535/arm.2012.36.3.365

7.Hamdy S, Jilani S, Price V, Parker C, Hall N, Power M. Modulation of human swallowing behaviour by thermal and chemical stimulation in health and after brain injury. Neurogastroenterol Motil 2003;15:69-77.

http://dx.doi.org/10.1046/j.1365-2982.2003.00390.x

8.Cola PC, Gatto AR, Silva RG, Spadotto AA, Schelp AO, Henry MACA. The influence of sour taste and cold temperature in pharyngeal transit duration in patients with stroke. Arq Gastroenterol 2010;47:18-20.

9.Cola PC, Gatto AR, Silva RG, et al. Taste and temperature in swallowing transit time after stroke. Cerebrovasc Dis Extra 2012;2:45-51.

http://dx.doi.org/10.1159/000339888

10.Rousmans S, Robin O, Dittmar A, Vernet-Maury E. Autonomic nervous system responses associated with primary tastes. Chem Senses 2000;25:709-18. http://dx.doi.org/10.1093/chemse/25.6.709

11.Okubo PCMI, Dantas RO, Troncon LEA, Moriguti JC, Ferriolli E. Clinical and scintigraphic assessment of swallowing of older patients admitted to a tertiary care geriatric ward. Dysphagia 2008;23:1-6.

http://dx.doi.org/10.1007/s00455-007-9087-2

12. Gomes FR, Secaf M, Kubo TTA, Dantas RO. Oral and pharyngeal transit of a paste bolus in Chagas' disease. Dysphagia 2008;23:83-7. http://dx.doi.org/10.1007/s00455-007-9101-8

13.Silva ACV, Fabio SRC, Dantas RO. A scintigraphic study of oral, pharyngeal, and esophageal transit in patients with stroke. Dysphagia 2008;23:165-71. http://dx.doi.org/10.1007/s00455-007-9117-0

14.Alves LMT, Fabio SRC, Dantas RO. Effect of bolus taste on the esophageal transit of patients with stroke. Dis Esophagus 2013;26:305-10.

http://dx.doi.org/10.1111/j.1442-2050.2012.01366.x

15.Schall R. Estimation in generalized linear models with random effects. Biometrika 1991;78:719-27.

http://dx.doi.org/10.1093/biomet/78.4.719

16.Argon M, Secil Y, Duygun U, Aydogdu I, Kocacelebi K, Ozkilic H, et al. The value of scintigraphy in the evaluation of oropharyngeal dysphagia. Eur J Nucl Med Mol Imaging 2004;31:94-8. http://dx.doi.org/10.1007/s00259-003-1276-0

17.Shaw DW, Williams RBH, Cook IJ, Wallace KL, Weltman MD, Collins PJ, et al. Oropharyngeal scintigraphy: a reliable technique for the quantitative evaluation of oral - pharyngeal swallowing. Dysphagia 2004;19:36-42.

http://dx.doi.org/10.1007/s00455-003-0033-7

18.André JM, Beis JM, Morin N, Paysant J. Buccal hemineglect. Arch Neurol 2000;57:1734-41.

http://dx.doi.org/10.1001/archneur.57.12.1734

19.Baroni AFFB, Fabio SRC, Dantas RO. Risk factors for swallowing dysfunction in stroke patients. Arq Gastroenterol 2012;49:118-24.

http://dx.doi.org/10.1590/S0004-28032012000200005

20.Landis BN, Leuchter I, San Millán Ruiz D, Lacroix JS, Landis T. Transient hemiageusia in cerebrovascular lateral pontine lesions. J Neurol Neurosurg Psychiatry 2006;77:680-3.

http://dx.doi.org/10.1136/jnnp.2005.086801

21.Palmer PM, McCulloch TM, Jaffe D, Neel AT. Effects of a sour bolus on the intramuscular electromyographic (EMG) activity of muscles in the submental region. Dysphagia 2005;20:210-7.

http://dx.doi.org/10.1007/s00455-005-0017-x

22.Alves LMT, Dantas RO. Percepção de sabores em pacientes com acidente vascular encefálico. Rev CEFAC 2011;13:1081-5.

http://dx.doi.org/10.1590/S1516-18462011005000098

23.Babaei A, Kern M, Antonik S, Mepani R, Ward BD, Li SJ, et al. Enhancing effects of flavored nutritive stimuli on cortical swallowing network activity. Am J Physiol 2010; 299:G422-9.

24.Mak YE, Simmons KB, Gitelman DR, Small DM. Taste and olfactory intensity perception changes following left insular stroke. Behav Neurosci 2005;119:1693-700

http://dx.doi.org/10.1037/0735-7044.119.6.1693 